\begin{tabular}{l|l} 
articulos & "DATA IOURNALISM"', \\
& AN INVESTIGATION \\
& PRACTICE? \\
& A glance at the German and Greek cases
\end{tabular}

Copyright @ 2015 SBPjor / Associação Brasileira de Pesquisadores em Jornalismo

\author{
JULIETTE CHARBONNEAUX \\ CELSA Paris-Sorbonne, France
}

PERGIA GKOUSKOU-GIANNAKOU

Université Blaise Pascal (Clermont-Ferrand 2)

\begin{abstract}
This contribution explores the links between the traditional work routines in investigative journalism and those, emergent ones, in " data journalism ». How do the European journalistic cultures react to this phenomenon, widely considered as a potential vector of profound destabilization of the established professional practices of the field and thus redefining the - fuzzy per se - contours of a profession that is already questioning its future? The issue here is to examine the extent to which the discourse on " data journalism » also reflects investigation practices and, through it, the professional ethics and journalistic ideals. With this intention, we put in parallel two European cases, namely the German the Greek one. The comparison of the two cases, by getting into the details of this proximity, clarifies the structuring of a professional discourse, the imaginaires feeding it on, and highlights - through the rhetoric of visualization - how the implicit dimension in the discourse about "data journalism" relates to a great extent to the way the information is given to read.
\end{abstract}

Key words: Data-journalism. Germany. Greece. Imaginary. Investigative journalism.

\title{
O JORNALISMO DE "DADOS”, UMA PRÁTICA DE INVESTIGAÇÃO? Um olhar sobre os casos alemão e grego
}

RESUMO - Esta contribuição explora a relação entre as rotinas de trabalho tradicionais do jornalismo investigativo e rotinas emergentes do jornalismo de "dados". Como as culturas jornalísticas europeias reagiram a esse fenômeno, geralmente considerado como um vetor potencial para uma profunda desestabilização de práticas profissionais já estabelecidas no campo? E, para além disso, em que medida elas provocaram uma redefinição das contornos - já imprecisos - de uma profissão que atualmente tem questionado o seu futuro? Este artigo busca examinar em que medida o discurso sobre o jornalismo de "dados" também reflete as práticas do jornalismo investigativo e, nesse sentido, a ética profissional e os ideias jornalísticos. Com esse objetivo, trabalhamos com dois casos europeus, o alemão e o grego. A comparação dos dois casos, por meio de uma análise detalhada da proximidade dessas práticas, permite entender o processo de estruturação do discurso profissional, os imaginários que o alimentam, e o destaca - por meio de uma visualização retórica - como a dimensão implícita aos discursos sobre o jornalismo de "dados" está profundamente relacionado à forma como a informação deve ser lida.

Palavras-chave: Jornalismo de dados. Alemanha. Grécia. Imaginário. Jornalismo investigativo. 


\section{EL PERIODISMO “DE DATOS”, ¿UNA PRACTICA DE INVESTIGACIÓN? Una mirada sobre los casos alemán y greco}

RESUMEN - Esta contribución explora la relación entre las rutinas laborales tradicionales del periodismo de investigación y las rutinas emergentes del periodismo de "datos". ¿Cómo las culturas periodísticas europeas contestaran a ese fenómeno, generalmente considerado un vector potencial de una profunda desestabilización de las prácticas profesionales ya establecidas en el campo? Y, más que eso, ¿cómo ellas han provocado una redefinición de les contornos - ya imprecisos - de una profesión que actualmente cuestiona su futuro? Este artículo examina de que manera el discurso sobre lo periodismo de "datos" reflete también la practicas del periodismo de investigación, pero también la ética profesional y los ideales periodísticos. Para cumplir este objetivo, trabajamos con dos casos europeos, lo alemán y lo greco. La comparación de los dos casos, a partir de un estudio pormenorizado del la cercanía de esas prácticas, permite entender los procesos de estructuración del discurso profesional, los imaginarios que lo alimentan y destaca - por medio de una visualización retorica - como la dimensión implícita a los discursos sobre el periodismo de "datos" está profundamente relacionada a la manera como la información debe ser leída.

Palabras clave: Periodismo de datos. Alemana. Grecia. Imaginario. Periodismo de investigación.

\section{INTRODUCTION}

The As a recent, fuzzily outlined topic, "data journalism", having initially emerged in the North-American media landscape (For some authors, "data journalism" is always considered as a North-American peculiarity (PARASIE, DAGIRAL, 2013a; 2013b), is gradually reaching Europe. In the lines of "computer assisted reporting" (GARRISON, 2001), this new form of journalistic writing is characterized by complex work and collaboration methods, bringing together journalists, data processing specialists and academics.

In this contribution, we explore the links between the traditional work routines in investigative journalism and those, emergent ones, in "data journalism". As Parasie and Dagiral have shown (2013a; 2013b), in the United States data journalists had initially worked in close cooperation with traditional investigation journalists even if their methods had been different. Is this the case on the other side of the Atlantic? In turn, how do the European journalistic cultures react to this phenomenon, widely considered as a potential vector of profound destabilization of the established professional practices of the field and thus redefining the - fuzzy per 
se - contours of a profession that is already questioning its future? Which types of discourse do these cultures mobilize in order to get along with it?

The issue here is to examine the extent to which the discourse on "data journalism" also reflects investigation practices and, through it, the professional ethics and journalistic ideals. More precisely, we intend here to study how does or does not the discourse on «data journalism» benefit from this heritage, how does it mobilize this heritage, and how does it adapt to professional "routine" practices. With this intention, we proceed to put in parallel two European cases, namely the German the Greek one. We chose to study the emergence of the "data journalism" in both countries, which can be viewed as complementary from the geopolitical aspect as well as their respective journalistic system structuring, since they are traditionally classified into if not opposed, at least distinct spheres (HALLIN and MANCINI, 2004). The development of this new journalistic movement takes place in distinct geopolitical contexts: in Greece, the first "experiments" of "data journalism" had been carried out in a context of deep economic crisis and scepticism of the citizens regarding the political leaders and the public institutions; in Germany the first projects of "data journalism" had tried to cast light on problems or unspoken comments behind the apparent political stability (the action of neo-Nazi gangs or the effectiveness of the public services). However, a double proximity between these two cases can be observed: the same trend for the actors self-defined as "data journalists" to posit themselves with respect to the old and established branch of the profession that is "investigation journalism" and the same propensity digital media (blogs personal, online news...) or traditional media (television, radio...) use in order to describe their work methods and show the social value of this new type of journalistic expression. The comparison of the two cases, by getting into the details of this proximity, aims at clarifying the structuring - by its reduction - of a professional discourse and the imaginaires feeding it on. Our work thus attempts to enrich and extend the work already completed that deals with the Anglo-Saxon countries (PARASIE 2012; 2013a; $2003 \mathrm{~b}$ ) and the more recent one on the Scandinavian countries (KARLSEN and STAVELIN, 2013). 


\section{METHODOLOGY AND CORPUS}

In order to address the questions raised here previously, we analyze the construction of the object "data journalism" in the professional discourse of the actors and the way they see themselves as mediators in the process of information building and dissemination.

At the same time, we question the relations between the new actors entering the journalistic field and investigation, relations that have to do with the technical and semiotic nature of the medium.

We adopt a socio-discursive approach and we question the discursive development related to "data journalism" viewed as a "moment" of the professional ethics discourse, which comes, in return, to empower journalism as "social practice of discursive production" (RINGOOT and UTARD, 2005, p. 18). Having this intention, we focus on the actors of two projects of processing and visualizing "data" in Germany and in Greece, a common point of these projects being the great publicity they gained in their respective countries as well as the "pedagogic" nature of their actors' discourse. Through their Web sites and their appearances in the media, seminars and conferences, they try on the one hand to convince professionals to adopt new methods and on the other hand the public to be put to new practices of information reading. In this way they present themselves as journalistic mediators. Moreover, most of their projects deal with national scale issues. We think that this fact reveals the imaginary of the role that this "journalism in invention is being given": the role of a foreground political actor at a nationwide level.

The German case we study is Lorenz Matzat's blog Datenjournalist.de. Installed in Berlin, Lorenz Matzat is a freelance, highly respected and acknowledged journalist in the German journalistic field: he is regularly contracted by traditional media, his productions have received several prizes and he is consequently very often invited to public intervention panels or interviews that have contributed to be highly regarded as "expert" of the journalistic exploitation of "data".

The semiotic-discursive analysis whose results are presented here was carried out from a "corpus in the corpus", consisting of posts and articles related to two projects, initiated completely or in part, 
by Matzat: the first one is called Rechtes Land (country of the Right) and the second one Zugmonitor (trains monitor), which has been implemented for the site of the German daily Süddeutsche Zeitung. The first project proposes to shed light upon the exactions committed by the neo-Nazi gang Nationalsozialistischer Untergrundnest (NSU: a terrorist cell of far Right) ${ }^{1}$ in German national territory, while the second presents "in real time" rail traffic nationwide.

The Greek case analysed is the Publicspending project ${ }^{2}$. This is the local branch of an international project on the collection, exploitation and presentation of information concerning public expenditure ${ }^{3}$. The ambitious objective of this project in the long run is to give the possibility of carrying out international comparisons on the crucial subject of national budgets. The Greek version of this program has a particular importance for two reasons: primo, it is the first project of presenting and processing of such data online; secundo, the situation the country has been experiencing during the last years (social conflicts and political instability because of the economic crisis). The creators of the project are initially engineers and designers coming from business and academia. With the collaboration of the journalists of the Greek daily press, they try to give answers to questions concerning the national expenditure on the basis of open data published by the Greek ministries on the Web. Born with the beginning from the economic crisis in Greece, this project's objective is to offer to the journalists a toolkit for following the evolution of the Greek economy over the last recent years.

More precisely, we have carried out nine semi-directed interviews with the nine partners of the Publicspending project ${ }^{4}$. The duration of the discussions was from forty minutes to one hour and the discussions (interviews given by telephone or Skype). In addition, we have also analyzed the discourse of the project coordinator (Mr. Vafopoulos) as developed into Web video clips $^{5}$.

We will describe first how the actors consider their relation to investigation journalism, and next we will analyse the methods they propose to renovate the latter. Finally, we will examine and draw attention to the imaginary that is carried by the respective methods of information formatting used in the projects of both cases in order to achieve their announced objective, that is the "interactive map". 


\section{DECLARATIONS OF INTENTIONS}

\subsection{IN GERMANY: CLAIMING A NEW APPROACH FOR AN IMPROVED INVESTIGATION}

Part of the activity of Lorenz Matzat on datenjournalist.de consists of defining what "data journalism" is about. In one of his very first posts, he mentions that "data journalism" has the ability "to widen the comprehension news covering of company and nature". "Given the success of the Wikileaks project, the role of the data in the field of journalism of investigation does not need to be further proven here ${ }^{7}$, continues the author.

Lorenz Matzat considers "data journalism" first of all as a branch to be put at the service of an already established speciality. Two years later, this kind of journalism seems to be more confirmed in the discourse of Matzat, who considers it further as a stand-alone investigatory practice, borrowing from the latter its approach and vocabulary:

\footnotetext{
"data journalism" can get a "scoop", can reveal a scandal. But it is essentially about enigmatics: the processing and representation of complex links which would be unperceivable in text or in tabular form. A succeeding data journalism offer the reader an environment of interactive research thanks to which they can form their own idea ${ }^{8}$.
}

One may perceive the imaginary emerging through these terms as the imaginary of investigation; except that this one is no more mentioned, as if "data journalism" had replaced it while going to hunt over its field, using its operating mode: "research". This mode of devising the approach contributes to adding value to the journalist's professional activity and, more broadly, to the role he is supposed to have in society.

Indeed, German "data journalism" is built as a promoter of the democratic political ideal. Thus, Loretz Matzat states that "The release of information is an essential component in politics. The Zugmonitor, with its political components, participates in the democratisation of knowledge about a capital institution for the society ${ }^{9}$. . when he is presenting the project on the railways schedules, repeating the rhetoric developed by "open data" movement and the Anglo-Saxons "data journalism" pioneers"

The right to information for all proclaimed here seems to be rather an ideal to assume and to cope with, than an ideal forsaken 
by others. In the case of Zugmonitor, it is a deficit of "transparency" of one of the last national state large enterprises (Deutsche Bahn), which must be filled. Thus, the project is presented as: "a form of recourse [of the company] to its own means to the extent that the political power and the state enterprise are still lagging behind with respect to the potential of Internet and where transparency is all but a forbidden word ${ }^{11}$.

If the public authorities are to be accused, the (other) media are also responsible according to our mediating figure. Additionally, this double discourse of denunciation is also cast by prominent figures of investigation journalism (ROBERT, 2012, p. 154). The difference here is that the journalism of investigation is absent here. Thus, sharing potentially common work goals, the two branches can compete eachother. In a post of his blog with the provocative title, "The NSU and the renouncement of journalism 12", Lorenz Matzat justifies the project developed around shedding light upon the clandestine neo-Nazi exactions while positioning himself clearly as the "essential marginal":

this has started with stating that apparently no team of investigation or no journalist in mainstream media during last years has cast any doubts on the official tale of the 'döner murders ${ }^{13}$. The corporation, which is readily considered as the fourth estate of the State, would have here been more essential than ever and it failed in its duty ${ }^{14}$.

Referring to the works of Dominique Marchetti on "investigation journalism", we can in this sense consider "data journalism" as a new "object of symbolic struggles related to the very definition of journalistic activity". Indeed, for the German actors of "data journalism" too, "it is not only any more a question of struggling against the amateurs but of contesting some professionals beyond the traditional bad examples of paparazzis or corrupt journalists who are supposed to threaten the honour of the profession" (MARCHETTI, 2000, p. 37).

If the professionals that Dominique Marchetti has in mind counted on the investigation to improve journalism, here it is a question of making an additional step to improve investigation, by using computerized media's practices of writing. 


\section{2. "INVESTIGATION JOURNALISM" AND "DATA JOURNALISM" IN GREECE: THE “WEBSCIENCE” SERVING A “DIFFERENT JOURNALISM OF INVESTIGATION"?}

The "data journalism" in Greece is now a fully emerging phenomenon, related to "open data" releases. This kind of journalism is competing with the traditional work methods of those considered specialists in journalistic investigation and is putting into question their practices of documentary research. In fact, since the institution of the law on the "State-citizen relation" $(6 / 11 / 1986,1599 / 1986)^{15}$ and in particular the article 16 on the "right of access to the public administration documents", all Greek citizens have access to the administrative documents ${ }^{16}$. However, the complexity of the access system, in particular before the generalization of the use of Internet, had left only to investigation journalists the possibility to carry over specialized document research in this field in order to compare, check or prove their information. Thus, the journalism of investigative journalism in Greece - often practised by solitary, even marginal journalists ${ }^{17}$ or by reporters integrated into large daily newspapers teams $^{18}$ - had hitherto mostly worked on revealing great issues of social interest (economic and/or political scandals) through the rough publication of documents that had gone public but were remaining practically difficult to reach.

Since 2010 , Greece has officially entered "the open data era", with the legal requirement for publishing on the Website Diavgeia (Transparency) (http://diavgeia.gov.gr/en) all administrative acts of the Greek State. In this way, the - printed yet not possible to processpublic data give their place to the "open data", released in formats which allow for being processed and reused ${ }^{19}$. However, continuous flows of this information are often considered as hard to decipher, understand or use by "not-specialists". Thus, the use and exploration of these data initially attracted only impassioned data processing and webspecialists. Within this framework, the project Publicspending initially conceived in 2011 by a few engineers/ data processing specialists, designers and academics of the National Technical University of Athens, had as main objective to initiate the Greek journalists into the universe of "data journalism". As its partners define it, this project is about teaching journalists to use open data and it is mostly addressed to them while in a second time, it concerns any interested person. The team of Publicspending are being defined themselves as "scientists of 
the Web" to the service of the journalists ${ }^{20}$. For them, journalists must learn and understand that a large number of data are on the Web:

\begin{abstract}
We are not journalists of investigation but we are serving investigation journalism [...] on the Web, there is a layer of objective information to which we have all access and the journalists are not trained to that. The journalistic mentality and practices are closed data- oriented. We have grown up with the mentality of closed data, we always think that it is necessary for us to have personal networks to find information (M.V., Coordinator of the Publicspending project).
\end{abstract}

However, the Publicspending project coincides with the beginning of the national debt crisis in Greece, that came after a series of financial disturbances. Moreover, it is precisely at this period that all the decisions taken by the Greek State are put online on the web http://diavgeia.gov.gr site. In this animated context, governmental "open data" are viewed with scepticism or indifference and the journalists express their doubts about the number and the nature of the decisions put online, concerning public expenditure of State establishments and institutions ${ }^{21}$. At the same time, along with the work of the established investigation reporters, a new journalistic movement, based only on the research and the processing of data published on the Web, is being developed.

Between the old and the new professionals of journalism, the mediators of "data journalism" try to act as tutors teaching the new professional routines and information research methods.

\title{
4. TWO “DISCOURSES OF THE METHOD” FOR “DATA JOURNALISM"
}

\subsection{GREEK SIDE: "SOURCES” AND “DATA” OR TWO METHODOLOGIES IN COMPETITION}

In Greece, data journalist methods raise the question of the distinction between "sources" of information or "data" to process.

Indeed, investigation journalists in Greece aim to reveal "hidden truths" concerning above all corruption, economic scandals or the under-the-table parts of political arrangements ${ }^{22}$, i.e. "actions justifying lawsuits or special services investigation". However, these data are often contained in "secret" documents, private or of disputed credibility, a reason for which most of such scandals never get completely elucidated ${ }^{23}$. 
Contrary to the traditional investigation journalism, the sources of the Publicspending project are only official documents found on the Web. The project partners present their project as "a free, open, neutral and objective Web application" 24 and the opposition between sources and data becomes more present than ever:

The Web is seen as an enormous database. If information is well presented, it is possible to formulate queries "[...] "We make such questions and we discuss them on an objective basis (for instance, 'which is the exact sum total of actual expenditure'), on true data and not on running unsigned rumours ${ }^{25}$.

"Objectivity" is guaranteed by the abundance of information on the Web. In the discourse of these "web scientists", the influence of the organicist metaphor of Robert Wiener shows up ${ }^{26}$ : information circulates freely in cyberspace and the digital media writing cannot guarantee anything but the truth. On the other hand orality is subjective and suspect as humans are.

Within this framework, the metaphor of the "questioning the Web" leads the Publicspending's creators to conceive a search engine making possible to formulate precise questions about public agencies' or private companies' State funding:

Figure 1 - Search engine to "question the Web"

8 where my money goes insername 0

INTRAKOM ANŌNYMIETTAIRIA SYMMETOCHŌN

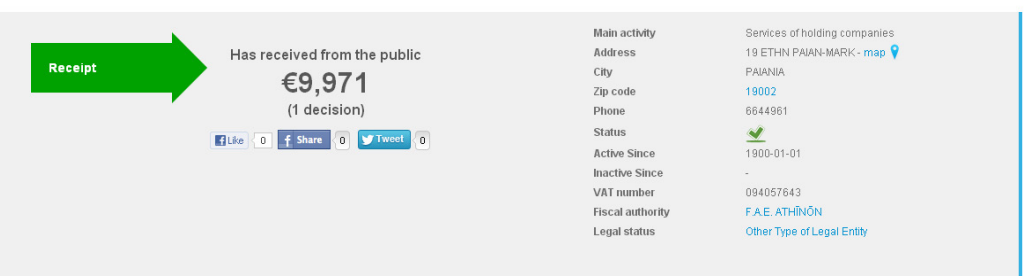

Source: www.publicspending.net

The metaphor of the space containing all the knowledge of the world, the ultimate place of collective memory recalls the ideal of the first libraries of the ancient world (JACOB, 2007). The journalistic news is "structured information" and the journalists must provide the research and consultation tools to the readers. In this context, programming becomes an essential journalistic method ${ }^{27}$. 
However, collaboration with the journalists presupposes the consistency of two contradictory professional logics: the logic of "webscientist" which collects information on the Web and the logic of journalist, who seeks a precise answer to a question. The "webscientist" works methodically by attentively mining large quantities of data. The investigation journalist often works under emergency conditions and with the preoccupation of continuously synchronizing with the rhythm of news imposed by audio-visual media (KARKLSEN and STAVELIN, 2013).

Since September 2012, the actors of Publicspending have struck a collaboration deal with three economic newspapers. Within the framework of these partnerships, the principal stake is the semantic contextualisation of data.

The recognition of data which are the most relevant with respect to the information that will be requested within the framework of targeted investigations, constitutes a major difficulty for the communication between journalists and data processing specialists: "The contextualisation is of very great importance. If somebody makes a noise without being capable of contextualizing it, this is a problem. Here lies the problem with the data: we do not understand what the problem looks like" (A.P., working for the project).

"Telling a story" constitutes a journalistic practice which hardly combines with the "language of numbers" that characterizes the data. This professional routine which characterizes journalistic writing is not part of the competences of these "data processors". Moreover, the journalists have learned how to work in emergency conditions to build short stories of revelation while the data processing specialists of the Web test slowly and thoroughly to put in order and to visualize all the information of the web: "Currently, we have 5000 administrative decisions 'to organize' We operate like that" (A.P.)

\subsection{GERMAN DISCOURSE OF THE METHOD: TOWARDS NEW ROUTINES OF "TRANSPARENCY"?}

In Germany too, this journalistic exercise implies, for our mediating figure, a didactic behaviour stance. Lorenz Matzat's "discourse on the method" consists thus in two major axes: a) giving examples of traditional practice's flaws to avoid, b) on the other hand, promoting of "good practices". 
In the post where he explains the raison d'etre of the project of neo-Nazi gangs monitoring, Matzat also deplores that "no major media has yet ever used the potential of the web for this case, thus breaking itself the installed dullness ${ }^{28}$. Then, he puts hyperlinks referring to the pages of four newspapers' websites that are related to the subject ${ }^{29}$. Counting on the fact that his readers have already gone to view themselves these cases presented as examples to not follow, he continues by pointing out a list of what these media could (and should) have done:

\begin{abstract}
it would nevertheless have been quite natural to create a platform or precisely a data bank which progressively gathers (...) all the knowledge (that is also worth for other topics like the crisis of the euro): who are the people and the actors (victims, families, criminals, police officers, agents of information, policemen, politicians, etc), which are their interests and until which point their loyalty goes, how they are connected between them; what are the established facts; which subject is concerned by which rumours and what are the hints supporting them and where do these rumours come from; at which place are there contradictions. All that could have been skilfully implemented in interactive form on a dedicated page and such a page would constitute an invaluable service (and would also bring many clicks). To represent an event in a clear way, to make it accessible, that's what I think journalism stands for. To this end, every possibility should have been used ${ }^{30}$.
\end{abstract}

One can easily interpret the shallow syllogism in the previous citation: the media mentioned have not done what it would be necessary to represent the event, so they do not make real journalism. The objective is nothing less than pointing out - in order to redefine them - the fundamental principles of the profession which is not confined any more to only a few types of medium but it is taken as a whole, "journalism". These comments on media production let us perceive the details of implementation of some ideal of transparency. The first of them, consists in exposing in detail the method mobilized to carry out "data journalistic" productions. Whereas the editorial enunciation is a process that remains "largely invisible by the public" (JEANNERET, SOUCHIER, 2005), its telling is an integral part of the device. Thus, the approach is presented by itself as being transparent.

For example, Süddeutsche Zeitung's website offers access to the backstage of the Zugmonitor project, through a special page with the meaningful title: "workshop report: how Zugmonitor has been brought out"31. The term of "workshop" connotes an artisanal, natural aspect, an absence of manipulating, and reveals the "manufacturing procedure". This article, written by Lorenz Matzat, is structured in eight explanatory paragraphs with subtitles whose form looks like a course. A typical subtitle: "what the journalists should retain from this project"32. 
A few months after the post denouncing the failing practices of the other media on the issue of the neo-Nazis exactions, Lorenz Matzat publishes a new post with the heading "On the project of data Rechtes Land and the possibilities of the crowdfunding in journalism"33. This latter post points to the former one with a hyperlink put in its beginning, making thus possible to the author to demonstrate the coherence of its approach by giving the impression of continuity. This hyperlink construction calls for comparison between bad and good practices, his owns being naturally classified into the second category. The two subtitles reveal his intention to show the way this project has been realized: "how the project was born? ${ }^{34 "}$ and "why did that finally go? ${ }^{35 " . ~ I n ~ t h e s e ~ t w o ~ p a r a g r a p h s ~ t h e r e ~ a r e ~ d e l i v e r e d ~ n o t ~ l e s s ~ t h a n ~} 21$ figures (cost of the operation, how many participants, duration of the project, etc). This quantification is a sign of $a$ "teaching and didactic mediation" (CANDEL, 2008, p. 38). "In social issues, to give a figure, a measurement, a digital development of the object of discussion, it is to bring to that the character of exactness, the presumably obvious and indisputable validity, which carries a statistical or mathematical processing, a measure" (CANDEL, 2008, p. 44).

On the other hand, this power of the figure is not displayed in Lorenz Matzat's discourses as an element that has to appear imperatively in the final online information. It is like being reabsorbed in a privileged device which it fits in. This device is the map. The map as a reasoned image, characterized by the "imposition of the reason" guarantees a "structural objectivity" (DASTON, GALISON, 2007, p. 98).

\section{OBVIOUSNESS OF THE “INTERACTIVE MAP”: INCREASEMENT AND TRANSPARENCY IN DATA EDITING}

In both fields, Greek and German, the tools and the detailed procedures aim to make possible the visual translation of the examined "data". If any production of information passes by its implementation to an "image of text" (SOUCHIER, 1998), therefore by the configuration of the mode in which it will be visually perceived, for our actors, the visualization constitutes a real innovation and by that, precisely, a major added value obtained by "data journalism". In both cases, this valuation passes by an object supposed to bring the optimal incarnation of "transparency". This object is the "interactive map". 


\subsection{IN GREECE:}

The webscientists claim obtaining transparency through quantifiable and visually represented journalism. However, as Thierry Libaert observed already in 2003, "henceforth, it's exceptional to read a newspaper without falling into a call upon transparency" (LIBAERT, 2003, p. 6). During a period of crises and disturbance, the concept of "transparency" has enormous success, it meets with those of "democracy" and "justice" and in this context the media are invited to make society to be "transparent towards itself" (LIBAERT, 2003, p. 14).

In the case of "data journalism", transparency is expressed through an hypermediatized image is $^{36}$ as product of digital technology, an augmented image which gives access to a paradoxical immediacy"3: "to see" the reality means to look "beyond" this reality using the digital support. The outspreading of data on a map is not related only to the geographical representation of reality, but in particular to the setting-toimage of heterogeneous and often abstract information as it is the case for the numerical figures. These new cards/diagrams must show the geographical positioning, the statistics and the conceptual analysis of the data, through a multi-media support containing simultaneously text, audiovisual documents and advanced computer graphics. As Yves Jeanneret notes, transparency is justified "particularly by a technicist discourse, which gives rise to thinking that the improvement of the devices would automatically generate effects of social transparency" (JEANNERET, 2005, p. 137.).

The metaphor of the interactive map, inherent in the Web, is used in the "data journalism" writing in order to give the impression of absolute transparency at every level of visualization of reality. In the image that follows, the connected bubbles showing the connections between the organizations and companies that receive the most important funding by the Greek State refer to the idea of universe. More precisely, the organizations dependent on national budget are represented by bubbles of size proportional to their turnover and of color varying from pure blue (private companies) to pure red (public sector). The arrows between the bubbles represent money flows (funding). 
Figure 2 - Publicspending projet: Companies funded by the State

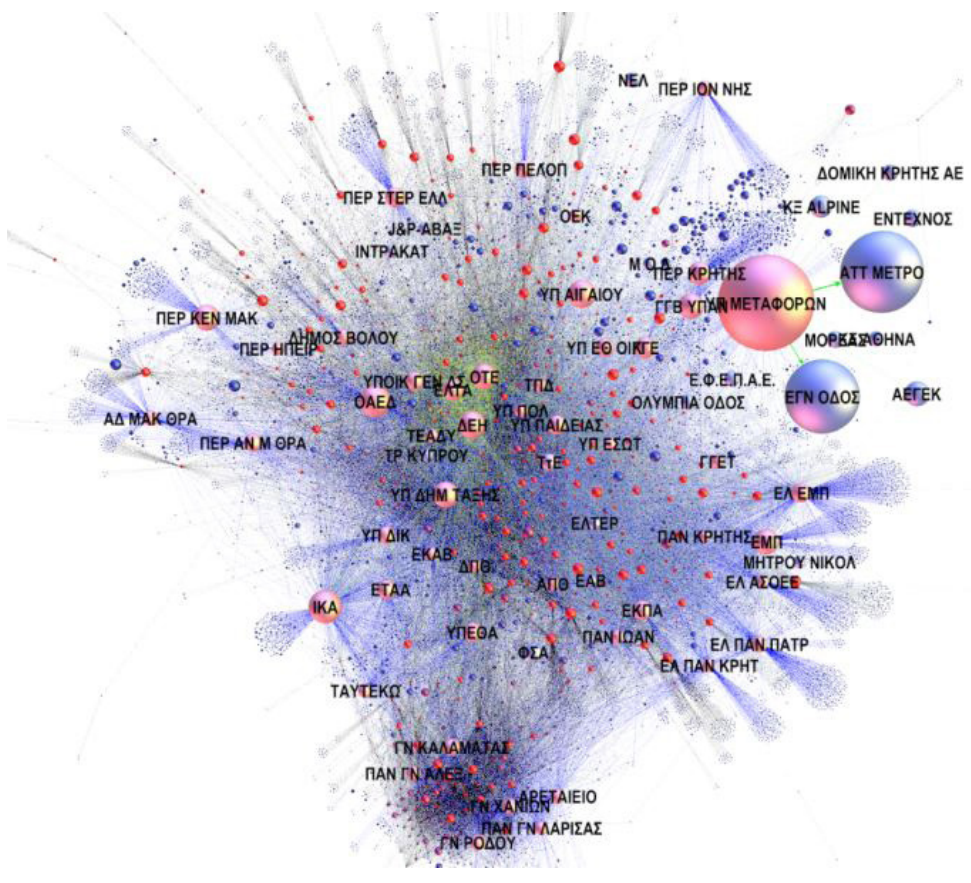

Source : www.publicspending.net

This universe identifies with and at the same time is distinguished from tangible, accessible reality outside the digital world. The metaphor of the map and the "bubbles" intervenes thus to the practice of journalistic writing, to modify the professional routines of the journalists: to tell a story is not any more to write a text with a beginning and an end, but rather to describe a universe which cannot be perceived through direct presence.

\subsection{IN GERMANY:}

In the discourse of Matzat, the imaginary of the map becomes enriched by the one of "interactivity". In connection with the development of the project on neo-Nazi crimes, he notes that "the recourse to an interactive map got self-imposed" 38 . This formulation give us an idea of the point to which the methods of storytelling are already perfectly incorporated in his discourse. This is a sign of a way completely traversed by both the imaginary of practices and 
their routinisation. He takes a further step when giving this map to sight, by a skilful process of "setting in abyss": the text of the post is completed by a video that had served to fundraising for the project and the image "of entry" in the video is no other but the interactive map in question. On this still image, waiting for the video play click, the production shown is not named "map" but "Atlas". The term further connotes exhaustiveness - an atlas is a sum of cards - and scientificity. The "project of knowledge, often pragmatic but ideological as well" that "supports" the object map is then completely mounted (LASCOUMES, 2007, p. 2-3).

Figure 3 - Project on neo-Nazi crimes: Video of an interactive map

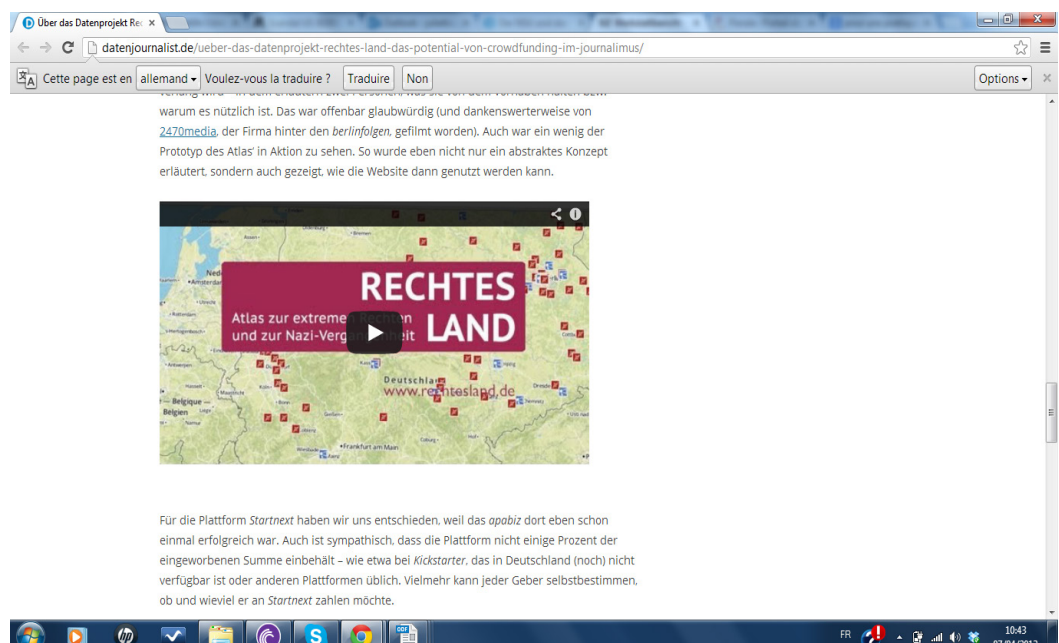

Source: www.datenjournaliste.de

The setting in abyss of the map continues in the film with an effect of redundancy which at the same time comes to legitimate and to naturalize it as informational object. The remarks of the first speaker, Ulli Jentsch, member of the Center of the antifascist press of Berlin, still underline the potential of the selected object: "The possibility opened with such a map, to summarize something like that and to continuously update the writing of it, is also the possibility of informing people on this subject in a sustainable way ${ }^{39}$ ".

While he pronounces these words, the map is displayed again behind him and afterwards in full screen. This time it is put in animation mode, as if that would prove the potential of "the interactivity" already highlighted in the talk of Ulli Jentsch. This visual 
demonstration echoes the remarks in the text of Matzat aiming at convincing the possible participants in the project for its scope: "the readers have a new experience: they can face a topic in an unusual, interactive way, search by themselves, and thus, directed by the facts, form their own opinion ${ }^{40}$ ".

After having reviewed the fabrication details, in other words, after having put in display the mediation, Matzat turns its discourse over and anything about the construction operation mentioned before fades out. The anticipation of the uses inscribed to the screen writings, the part of textualisation of practices, all disappear behind the place attributed to the reader and, especially, behind the ideology of transparency of the "facts". The setting afront of the media covers the mediation and its symbolic dimension ${ }^{41}$.

With the object "map" which brings about a semiotic extension that becomes stabilized and incorporated to the national character of the issues covered by Datenjournalismus, the democratic promise is renewed in writings which are those of the computerized media, based upon the ideological discursive formation of interactivity. Suggesting to the reader that he has at hand all the means to his reading, seems like giving him by the same gesture the power over information.

The interactive map becomes a performative metaphor: its reading achieves the democratic promise ideal. This is the place where the professional imaginary and the one of computerized media meet and amalgamate.

\section{CONCLUSION}

Through the rhetoric of visualization, we can perceive that the implicit dimension in the discourse about "data journalism" relates not only to the volume or the quality of "revealed" information as in the case of investigative journalism, but also to the same, if not greater, extent, to the way the information is given to read. The competition challenge between media passes then from a rhetoric of semiotic performance "haunted" by the illusion of the transparency. We can also see how a journalistic practice which is presented as resolutely new, not only reactivates the imaginary corresponding to older practices, but also defines itself through routinized practices. By teaching lessons on "data journalism", our mediating figures contribute to its routinisation while they claim to follow an innovative approach. 
It is precisely these new routines, related to the nature of the support and the upshowing of the imaginary specific to it, which engage a parallel discourse on "data journalism" as a new form of collaborative journalistic activity - forgetting along the way the intrinsically multiple aspect of any production of information, whatever the support is. The implementation of "datajournalistic" productions passes from the confrontation, in the discourse level, of a journalistic group "augmented" by the introduction of new competences (data processing specialists, graphic designers, developers...) or even by an association between a media corporation and a specialized structure as our two cases (the German and the Greek one) show. The "new jobs" are part of the definition and of the apprehension of this journalistic activity that views itself as new.

We can read in this a reaction to the ambient discourse that denounces the coming of the "amateurs" journalists of the Internet era. We include here the conclusions of the work of Denis Ruellan on the question of the "border" that has gradually been set up by journalists in order to circumscribe a professional field (RUELLAN, 1993; 1997). In the case of the "data journalism", on the other hand, (re-establishing this border is not done by refocusing on the activity but through an extension of the field of the professionalization, by integrating competences that connote themselves professionalism and such that the actors of journalism regain legitimacy when using them at work.

*This paper was translated by Pergia Gkouskou-Giannakou

\section{REFERENCES}

BOLTER, J. D.; GRUSIN R. Remediation: Understanding New Media. Cambridge: MIT Press, 1999.

CANDEL, E. Une ration quotidienne de statistiques. La pratique éditoriale du «chiffre du jour» dans la presse écrite. La Communication nombre, $n^{\circ} 28$, p. $37-52,2008$.

CHIGNARD, S. Open Data. Limoges: Éditions FYP, 2012.

DASTON, L. ; GALISON, P. Objectivity. New York: Editions Zone Book, 2007 
GARRISON, B. Diffusion of online information technologies in newspaper newsrooms. Journalism, vol. $2 \mathrm{n}^{\circ}$ 2, p. 221-239, 2001.

GRAY, J.; CHAMBERS, L., BOUNEGRU, L. The Data Journalism Handbook. O'Reilly: Sebastopol, 2012.

HALLIN, D.; MANCINI, P. Comparing Media Systems: Three models of media and politics. Cambridge: Cambridge University Press, 2004

JEANNERET, Y.; SOUCHIER E. L'énonciation éditoriale dans les écrits d'écran. Communication \& Langages, n¹45, p. 3-15, 2005.

JEANNERET, Y. Transparence. In: La « société de l'information ": glossaire critique. Paris: La Documentation Française, 2005, p. 137 138. Available in: http://www.diplomatie.gouv.fr/fr/lMG/pdf/Clossaire_ Critique.pdf. Access on: 02 jun. 2013.

KARLSEN, J.; STAVELIN, E. Computational Journalism in Norwegian Newsrooms. Journalism practice, 8 (1), p. 34-48, 2013.

LASCOUMES, P. Gouverner par les cartes. Genèses, n 68, Vol. 03, p. 0203, 2007. . Available in: www.cairn.info/revue-geneses-2007-3-page-2. htm. Access on: 02 jun. 2013.

LIBAERT, T. La Transparence en trompe-l'œil. Paris: Éditions Descartes et Cie/ Éd. Charles Léopold Mayer, 2003.

MARCHETTI, D. Les révélations du journalisme d'investigation. Actes de la recherche en sciences sociales, Vol. 131-132, p. 30-40, mar. 2000.

PARASIE, S.; DAGIRAL, E. Des journalistes enfin libérés de leurs sources ? Promesses et réalités du journalisme de données. Sur le journalisme, $n^{\circ} 2$, Vol. 1, 52-63, 2013a.

PARASIE, S.; DAGIRAL, E. Data-driven journalism and the public good: Computer-assisted reporters and programmer-journalists in Chicago. New media and society, vol. $15 \mathrm{n}^{\circ} 6$, p. 853-871. 2013b.

PARASIE, S. ; DAGIRAL, E. Quand le web colle au territoire : l'exploration de l'information hyperlocale à Chicago. Sciences de la Société, n 84 85 , p. 81-101, 2012.

REBILLARD, F. Le web 2.0 en perspective. Paris: L'Harmattan, 2007.

RINGOOT, R.; UTARD J.-M (Eds.). Le Journalisme en invention. Nouvelles pratiques, nouveaux acteurs. Rennes: Presses universitaires de Rennes, 2005.

ROBERT, V. Un remède à la crise de la presse ? Le journalisme d'investigation 
en France et en Allemagne. Dokumente/Documents, 4/2012, p. 165-168

RUELLAN, Denis. Le Professionnalisme du flou. Grenoble: Presses universitaires de Grenoble, 1993.

RUELLAN, D. Les « pro » du journalisme. De l'état au statut, la construction d'un espace professionnel. Rennes: PUR, 1997.

SOUCHIER, E. L'image du texte. Pour une théorie de l'énonciation éditoriale.

Les Cahiers de médiologie, n. 6, p. 136-146, décembre 1998.

NOTES

1 NSU (Nationalsozialistischer Untergrundest): a terrorist cell of far Right.

2 http://publicspending.medialab.ntua.gr/

3 It is about the project "Where public money goes world-wide? "; the countries which currently take part in this project are: the United States, the United Kingdom, Australia and Greece: http://www.publicspending.net/

4 The partners of the Publicspending project are: M. Vafopoulos, M. Meïmaris, I. Anagnostopoulos, A. Papantoniou, M. Klonaras, V. Loumos (Polytechnic school of Athens), I. Xydias, G. Vafeiadis (University of Egée, Greece), G. Alexiou (University Aristote de Thessalonique).

5 More precisely, we analyzed the following online videos: a) presentation of the Publicspending project by M. Vafopoulos in "Ignite Athens the 2012", put online 9/21/2012: http://www.dailymotion. com/video/xtra3s_\%CF\%80o\%CF\%85-\%CF\%80\%CE\%B 1 n\%CE\%B5oi-\%CF\%86 o\%CF\%8 1 оi-\%CE\%BCo\%CF\%85-publicspending-gr\%CF\%83\%CF\%84\%CE\%BF-ignite-athens-2012_tech b) “Digital Aegean”, $n^{\circ} 73$, Web broadcast put online: 2/6/2013: http://www.dailymotion. com/video/xxc2g0_73-aegean-digital-public-spending-010213_tech

6 "Das Verständnis von und die Berichterstattung über Gesellschaft und Natur erweitern.", Ibid.

7 "Welche Rolle Daten in Sachen investigativem Journalismus spielt, muss angesichts des erfolgreich Projekts Wikileaks hier nicht weiter ausgeführt warden", Ibid.

8 "Datenjournalismus kann einen "Scoop" erzielen, einen Skandal aufdecken. Aber meist geht es um Hintergründiges: Die Aufbereitung 
und Darstellung komplexer Zusammenhänge, die in Schrift oder Tabellenform unüberschaubarer wären. Gelungener Datenjournalismus bietet dem Leser eine interaktiven Rechercheumgebung an, mit dem er sich ein eigenes Bild machen kann", datenjournalist.de, 23/02/2012.

9 "Die Freigabe von Informationen bzw. deren Zurückhalten ist wesentliches Element von Politik. Der Zugmonitor trägt mit seiner politischen Komponente zur Demokratisierung des Wissens über eine bedeutende Infrastruktureinrichtung der Gesellschaft bei", http://datenjournalist. de/selbsthilfe-die-vier-dimensionen-des-zugmonitors/, 14/03/2012.

10 "Er ist eine Form von Selbsthilfe, weil etablierte Politik und staatliche Unternehmen immer noch Meilen hinter dem Potential des Internets hinterherhinken und Transparenz meist nur ein Lippenbekenntnis bleibt", http://datenjournalist.de/selbsthilfe-die-vier-dimensionen-des-zugmonitors/ , 14/03/2012.

11 "Er ist eine Form von Selbsthilfe, weil etablierte Politik und staatliche Unternehmen immer noch Meilen hinter dem Potential des Internets hinterherhinken und Transparenz meist nur ein Lippenbekenntnis bleibt", http://datenjournalist.de/selbsthilfe-die-vier-dimensionen-des-zugmonitors/, 14/03/2012.

12 http://datenjournalist.de/der-nsu-und-das-versagen-des-journalismus/, 06/12/2012.

13 http://datenjournalist.de/der-nsu-und-das-versagen-des-journalismus/, 06/12/2012.

14 This term, largely fallen in disparage eversince, was launched by the German Press to designate a series of assassinations of small entrepreneurs of Greek or Turkish origin committed by this neo-Nazi gang.

15 Downloadable from: http://www.et.gr/idocsnph/search/pdfViewer Form.htmlargs $=5$ C 7QrtC22 wEjGnbAWBkpTXdtvSoCIrL8R5ab $1 \mathrm{U}$ mX_HjtIl9LGdkF53UIxsx942CdyqxSQYNuqAGCFOIfB9HI6qSYtMQE kEHLwnFqmgJSA5WIsluV-nRwO 1 oKqSe4BIOTSpEWYhszF8P8UqWb_ zFijEMdAWOoH1WPRpSTQArLJheVYA5RrLeu76JoqvGJKUR9

16 A modification of this law in 1999 (2690/1999; article 5) widens the right of access to "each interested party".

17 For instance, the journalist/editor of the Hotdoc magazine, Mr. Kostas Vaxevanis. 
18 For instance, Mrs. Gianna Papadakou (Гı́́vva П $\alpha \pi \alpha \delta \alpha ́ \kappa o v)$, newspaper To Bí $\mu \alpha$ (La Tribune)

19 On the distinction between "public data" and "open data", see: Chignard (2012).

20 "We are defined as webscientists" (M.V., Coordinator of the Publicspending project) (our translation).

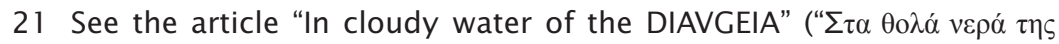

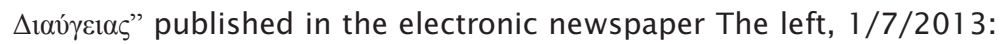
http://left.gr/news/sta-thola-nera-tis-diaygeias. In this article, the assertion that the totality of the ministerial decisions is published on the web, is put in doubt.

22 Subjects related to "questions which cause legal proceedings or to specialized investigations of the services" (MARCHETTI, 2000, p. 30).

23 In order to illustrate these remarks, we can take as example the faoues case of "phone-tappings" in 2006. It is about the existence of a network of illegal wiretapping installation by the mobile telephone company "Vodaphone" after the Olympic Games of Athens, revealed in particular by

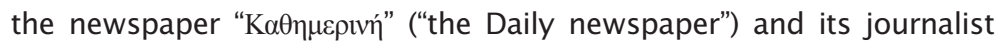
Aristea Bougatsou. Among the personalities put under listening were the Greek Prime Minister at the time, Kostas Karamanlis, and several of his ministers as 24 journalists working for seven different TV channels and newspapers. Even Vodafone was condemned to a fine 76 million euros by the Greek authority of Protection of communications (ADAE), the exact list of the names of the victims, was never confirmed.

24 "The "publingspending.gr" initiative has free, open, neutral and objectifies Web application" (our translation) (http://publicspending. medialab.ntua.gr/en/about.php).

25 Ibid.

26 On the "rebirth" of this metaphor in the Web journalism, see Rebillard (2007).

27 We point out here the results of the investigation of Sylvain Parasie and of Eric Dagiral (2012) near the American data journalists according to which the "news is structured information" and the journalists must produce research tools for readers.

28 "erstaunt es, dass kein größeres Medium sich den Möglichkeiten des 
Netzes bedient, um hier aus dem Einerlei hervorzustechen", http:// datenjournalist.de/der-nsu-und-das-versagen-des-journalismus/, 06/07/2012.

29 "Hier die Themenseiten der Süddeutschen, der Tagesschau, von Spiegel Online und der FAZ", http://datenjournalist.de/der-nsu-und-dasversagen-des-journalismus/, 06/07/2012.

30 "Ganz abgesehen davon, dass keine Redaktion ein dezidiertes Blog oder zumindest ab und zu etwa rund um Untersuchungsausschusstermine 'live' bloggt - es wäre doch eigentlich nahliegend, eine Plattform oder eben Datenbank aufzubauen, die prozesshaft in Text-, Bild-, Audio- und interaktiven Grafikformaten sammelt, was Kenntnisstand ist (das gilt für andere Themen auch, etwa der Eurokrise): Wer sind die Personen und Akteure (Opfer, Familien, Täter, Polizisten, Geheimdienstmitarbeiter, Politiker usw.), was sind ihre Interessen und wo liegen ihre Loyalitäten, wie sind sie miteinander verbunden; was sind bewiesene Fakten; worüber gibt es Gerüchte und was sind Indizien für sie und von wo stammen sie; an welcher Stelle gibt es Widersprüche. Das ließe sich alles mit einigem Geschick in interaktiver Form auf einer Themenseite anbieten, die einen wertvollen Dienst darstellen würde (und viele Klicks brächte). Ein Geschehen übersichtlich zu gestalten, aufzubereiten, zugänglich zu machen, halte ich für Journalismus. Und dabei sollte er sich allem bedienen, was möglich ist".

31 "Werkstattbericht : wie der Zugmonitor entstanden ist", http://www. sueddeutsche.de/kolumne/werkstattbericht-wie-der-zugmonitorentstanden-ist-1.1303418, 10/03/2012.

32 "Was Journalisten vom dem Projekt lernen sollen", http://www.sueddeutsche.de/kolumne/werkstattbericht-wie-der-zugmonitor-entstanden-ist-1.1303418, 10/03/2012.

33 "Über das Datenprojekt \& das Potential von Crowdfunding im Journalismus", http://datenjournalist.de/ueber-das-datenprojekt-rechtesland-das-potential-von-crowdfunding-im-journalimus/

34 “Wie kam es zu dem Projekt?", http://datenjournalist.de/ueber-das-datenprojekt-rechtes-land-das-potential-von-crowdfunding-im-journalimus/

35 "Warum es nun geklappt hat?", http://datenjournalist.de/ueber-das-datenprojekt-rechtes-land-das-potential-von-crowdfunding-im-journalimus/

36 We refer here to the concept of "hypermediation" by Bolter and Grusin (1996). According to David Bolter and Richard Grusin, the "hypermediation" indicates the recognition of a quality of reality to the experiment of media. 
37 Immediacy suggests the experience of a pure presence ("direct apprehension").

38 "Der Einsatz einer interaktiven Karte lag auf der Hand", http://datenjournalist.de/ueber-das-datenprojekt-rechtes-land-das-potential-voncrowdfunding-im-journalimus/

39 "Die Möglichkeit über so eine Karte, so was zusammenzufassen und so was kontinuerlich fortzuschreiben, ist eine Möglichkeit, um auch dauerhaft Leute darüber zu informieren", transcription of the video of the presentation of the project, http://datenjournalist.de/ueberdas-daten projekt-rechtes-land-das-potential-von-crowdfunding-imjournalimus/, 21/01/2013.

40 "Die Leser machen eine neue Erfahrung: Sie können sich mit einem Thema auf ungewohnte Weise auseinandersetzen, interaktiv, selber recherchieren und so faktenorientiert zu einer eigenen Einschätzung gelangen".

41 On this subject, see the discussion with Umberto Eco by Frédéric Lambert and Adeline Wrona (2011, p. 41).

Juliette Charbonneaux is associate professor at CELSA Paris-Sorbonne (Graduate School in Information and Communication Sciences) and member of the laboraty GRIPIC. In her research work she analyses the links between media and politics.

Pergia Gkouskou-Giannakou is associate professor at the Blaise Pascal University (ClermontFerrand 2) and member of the laboratories "Communication and Solidarity" (Blaise Pascal University) and GRIPIC (Celsa/Sorbonne). She is currently working on the social uses of digital media. 